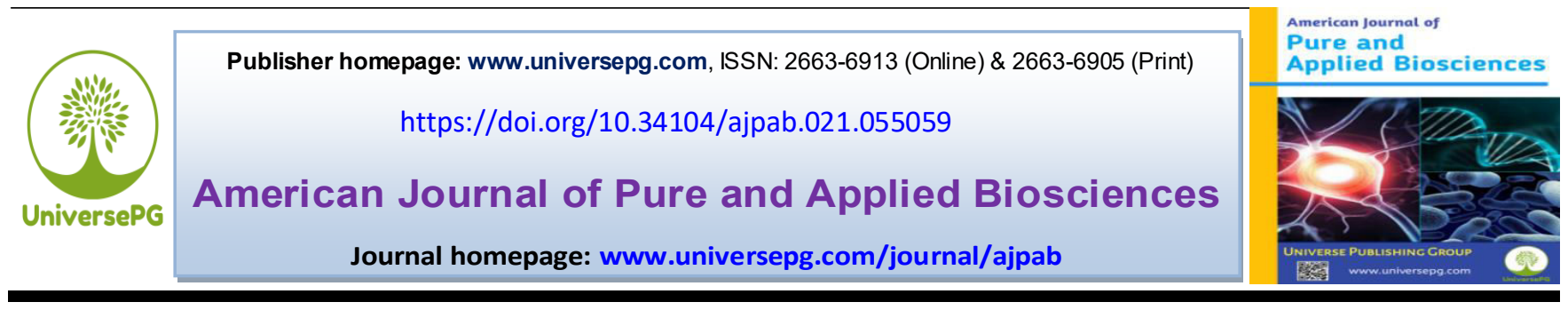

\title{
Effects of Different Biofertilizer on Soybean (Glycine max) Production
}

\author{
Md. Nazmul Islam ${ }^{1}$, Shaila Sharmin ${ }^{1}$, and Mohammed Ataur Rahman²* \\ ${ }^{1}$ College of Agricultural Sciences, International University of Business Agriculture and Technology (IUBAT), Dhaka, \\ Bangladesh; ${ }^{2}$ Centre for Global Environmental Culture (CGEC) and Program on Education for Sustainability Coordinator, \\ International University of Business Agriculture and Technology (IUBAT), Dhaka, Bangladesh. \\ *Correspondence: marahman@iubat.edu (Professor Dr. Mohammed Ataur Rahman, Director, Centre for Global Environ- \\ mental Culture (CGEC) and Program on Education for Sustainability Coordinator, WWOOF Bangladesh \& RCE Greater \\ Dhaka, Bangladesh).
}

\begin{abstract}
The experiment was conducted in the agriculture field of the International University of Business Agricultural and Technology (IUBAT), Dhaka, from January to June 2017 to find out the effect of different Rhizobium inoculations on soybean production. The experiment was set up in a Completely Randomized Design (CRD) with four replications. Eight Rhizobium inoculations and one control treatment were used in the study to assess the effect of different biofertilizers on soybean production. The findings of the study showed that Strain Bacteria (SB) 316 inoculant performed better in all aspects of growing parameters and yield components like nodulation, vegetative growth, and yield. However, the control treatment performed lowest in every parameter. As a result of the experiment, it could be concluded that Rhizobium inoculation has a significant effect on vegetative growth, nodulation, and yield component of soybean. The SB 316 inoculant has been found as the most effective Rhizobium inoculation in soybean production.
\end{abstract}

Keywords: Soybean, Biofertilizer, Rhizobium inoculation, Strain, Bacteria, Growth, Production, and Yield.

\section{INTRODUCTION:}

Soybean (Glycine max L.) is a globally important grain legume crop. Soybean is known as the golden beans of the $21^{\text {st }}$ century. As a grain legume, it is graining important position in the agriculture of tropical countries, including Bangladesh. It has huge potentiality and has emerged as an important commercial oilseed crop in Bangladesh. In Bangladesh, the soybean is cultivated mainly as pulses crops. The total annual production of global soybean in 2018 was 348 million metric tons (FAO, 2018). The major producers of soybean are Brazil, the United States, Argentina, China and India. The world average yield of soybean is 2.80 MT/ha (Lange Meier and Purdy, 2019) where our

UniversePG I www.universepg.com average yield is $1.59 \mathrm{MT} / \mathrm{ha}$, which is much lower than the world average soybean production. Our soybean production yield is much lower than the world average soybean production. Imbalanced nutrition is one of the major obstacles to low soybean productivity in Bangladesh. The application of biofertilizer into the soil leads to increase soil fertility and crop productivity (Yadav and Sarkar, 2019). Rhizobium is one of the dominant symbiotic nitrogen-fixation bacteria. As most of our soils are poor in organic matter, response to fertilizer has not been higher due to the rapid fixation of nutrients (Rabiul et al., 2020). Under such conditions, Rhizobium inoculation could be advantageous. To overcome these adverse effects the 
Rhizobium inoculation needs to be established with a high level of effectiveness. The application of Rhizobium inoculation increases plant growth, nutrient uptake and crop yields. Kazmi et al. (2005) reported that soybean seed inoculation by rhizobia bacteria significantly increases the yield. Effective bacteria add enough nitrogen by nodulation which is very important for the growth and development of the plant. It is also very crucial for improving soil fertility and productivity. The objective of the study is to find out the effects of different biofertilizer on soybean growth and yield.

\section{MATERIALS AND METHODS:}

The experiment was conducted in the agriculture field of International University of Business Agricultural and Technology (IUBAT), Dhaka, from January to June 2017. This experiment was performed to evaluate the effects of various biofertilizers on soybean production. The soil of the experiment was sandy loam. The experiment was set up in a Completely Randomized Design (CRD) with four replications. The crop used in the experiment was soybean (Glycine max) and the variety of the crop was BINA Soybean 3 .

The study comprised of eight Rhizobium inoculants treatments such as T2: SB-66, T3: SB-321, T4: SB306, T5: SB-316, T6: SB-343, T7: SB-394, T8: SB433, T9: SB-212, and one control treatment T1 (without any treatment). TSP and MOP fertilizers were used as source of $\mathrm{P}$ and $\mathrm{K}$ nutrition. No nitrogenous fertilizer was used during the experimental period. The Strain Bacteria (SB) was prepared in the agricultural laboratory of IUBAT, Dhaka. Some molasses was also used with the Strain Bacteria. Molasses and Strain Bacteria were well mixed in a petri dish at the rate of $15 \mathrm{ml}$ per $\mathrm{kg}$ and mixed well with the seeds thoro- ughly. For each treatment, a separate Petri dish and a separate hand globe were used to avoid contamination of the treatment. Seed inoculation was done on 02 February 2017 and inoculated seeds were shown in the field on the same afternoon. The spacing between the lines was $30 \mathrm{~cm}$ and between the plants was $5 \mathrm{~cm}$. Intercultural operations were done for ensuring and maintaining the normal growth of the crop.

The crop was harvested on $13^{\text {th }}$ May, 2017 by observing the physiological maturity. The harvested plant materials were allowed to dry in the sun for 3 days. After drying, threshing and processing was done carefully on a plot basis. The data collection was done at different dates from different parameters and collected data were analyzed statistically by using computer software, Statistics 10.

\section{RESULTS AND DISCUSSION:}

The ultimate objective of crop production is its economic yield. Seed yield is the major concern for soybean. The effects of biofertilizers on soybean production presented by their contributions to vegetative growth, nodulation, and yield.

Vegetative growth - The effect of different biofertilizer on the vegetative growth of soybean is measured in terms of plant height, weight and length. The effect of biofertilizer on vegetative growth of different treatments has shown that Rhizobium inoculation is more significant than the control treatment. Among the various Rhizobium inoculants, SB 316 treatment growth performance was a maximum in every aspect of growing parameters like plant height, shoot fresh weight, shoot dry weight, root length, root fresh weight, and root dry weight.

Table 1: Vegetative growth of soybean in different parameters

\begin{tabular}{|c|c|c|c|c|c|c|}
\hline Treatment & Plant height & Root length & $\begin{array}{c}\text { Shoot fresh } \\
\text { weight }\end{array}$ & $\begin{array}{c}\text { Shoot dry } \\
\text { weight }\end{array}$ & Root fresh weight & Root dry weight \\
\cline { 2 - 7 } & \multicolumn{2}{|c|}{ (cm/plant) } & & \multicolumn{3}{|c|}{ (gm/ plant) } \\
\hline Control & $90.5 \mathrm{c}$ & $38.25 \mathrm{c}$ & $165 \mathrm{~b}$ & $52 \mathrm{c}$ & $22.75 \mathrm{~d}$ & $6.75 \mathrm{~d}$ \\
\hline SB 66 & $119.5 \mathrm{~b}$ & $40.5 \mathrm{bc}$ & $203.25 \mathrm{~b}$ & $68.75 \mathrm{bc}$ & $25.5 \mathrm{~cd}$ & $3.75 \mathrm{~cd}$ \\
\hline SB 321 & $134 \mathrm{ab}$ & $45 \mathrm{abc}$ & $293 \mathrm{a}$ & $82.75 \mathrm{ab}$ & $30.5 \mathrm{bcd}$ & $8.75 \mathrm{bcd}$ \\
\hline SB 306 & $138 \mathrm{ab}$ & $49.25 \mathrm{ab}$ & $295 \mathrm{a}$ & $86.5 \mathrm{ab}$ & $37.25 \mathrm{ab}$ & $10.75 \mathrm{ab}$ \\
\hline
\end{tabular}




\begin{tabular}{|c|c|c|c|c|c|c|}
\hline SB 316 & $142 \mathrm{a}$ & $50.75 \mathrm{a}$ & $305.5 \mathrm{a}$ & $88 \mathrm{a}$ & $40.25 \mathrm{a}$ & $12.25 \mathrm{a}$ \\
\hline SB 343 & $136 \mathrm{ab}$ & $49.5 \mathrm{ab}$ & $285.75 \mathrm{a}$ & $82.25 \mathrm{ab}$ & $36.75 \mathrm{ab}$ & $9.25 \mathrm{bcd}$ \\
\hline SB 394 & $135.5 \mathrm{ab}$ & $47.25 \mathrm{abc}$ & $277.25 \mathrm{a}$ & $81.25 \mathrm{ab}$ & $36.5 \mathrm{ab}$ & $9.5 \mathrm{bc}$ \\
\hline SB 433 & $129 \mathrm{ab}$ & $46.5 \mathrm{abc}$ & $261.5 \mathrm{a}$ & $76 \mathrm{ab}$ & $32.25 \mathrm{abc}$ & $9.25 \mathrm{bcd}$ \\
\hline SB 212 & $132 \mathrm{ab}$ & $48 \mathrm{ab}$ & $266 \mathrm{a}$ & $81 \mathrm{ab}$ & $36 \mathrm{ab}$ & $9.75 \mathrm{abc}$ \\
\hline CV & 11.48 & 14.03 & 14.78 & 16.41 & 19.60 & 20.10 \\
\hline LSD & 21.40 & 9.41 & 56.05 & 18.47 & 9.40 & 2.72 \\
\hline
\end{tabular}

The Analysis of variance indicates that the Rhizobium inoculation has a significant effect on all plant growth parameters such as plant height, shoot fresh weight, shoot dry weight, root length, root fresh weight, and root dry weight. Among the various Rhizobium inoculations, the SB 316 treatment significantly increased the plant height and root length by $142 \mathrm{~cm}$ and 50.75 $\mathrm{cm}$, respectively. Similarly, a significant increase of $88 \mathrm{gm}, 40.25 \mathrm{gm}$, and $12.25 \mathrm{gm}$ was observed in the shoot dry weight, root fresh weight, and root dry weight, respectively. In contrast, to shoot fresh weight, SB 316 inoculant was less significant than other inoculations (Table 1). However, the lowest vegetative growth performance was observed from the control treatment. The increased vegetative growth might be due to the increased metabolic activities and stimulation of root growth resulting in enhanced uptake of nutrients. Jaga and Sharma, (2005) agreed with these findings who reported that bio-fertilizer adds nutrient additionally and increase plant growth activity.

Nodule - Rhizobium inoculation has a significant effect on plant nodulation. Different Rhizobium inoculation significantly influenced the number of nodule plant-1, nodule fresh weight plant-1, and nodule dry weight plant-1 (Fig 1). The highest number of nodules (57.5) recorded from SB 316 treatment. The maximum nodule fresh weight (27.75 gm) and nodule dry weight (3.4 gm) were also observed from SB 316 treatment. On the other hand, the lowest number of the nodule (26.25), nodule fresh weight (13.75 gm), and nodule dry weight $(1.27 \mathrm{gm})$ were found from the control treatment (Fig 1).

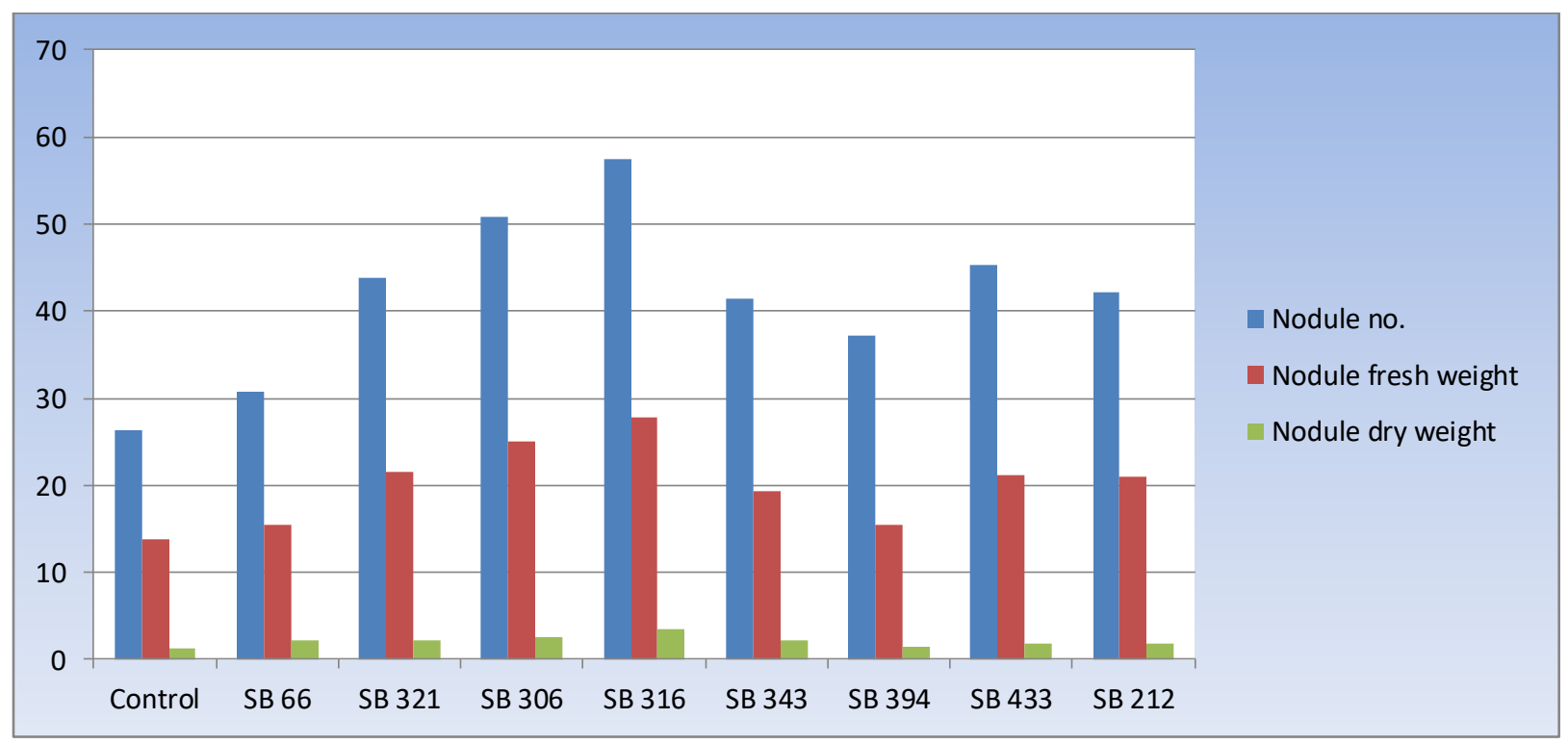

Fig 1: Nodule number, nodule fresh weight (gm) and nodule dry weight (gm) of soybean.

Rhizobia strain significantly increases plant nodulation. Nodulation enhances the crop yield remarkably. The increased nodulation may due to effective symUniversePG I www.universepg.com biosis between legume and rhizobia strains. Similar findings showed by Sultana et al. (2014) and Egamberdiyeva et al. (2004), who reported that soybean 
inoculation significantly increased the nodulation that affected the yield. The result of the experiment indicates that Rhizobium inoculation influenced the soybean inoculation significantly. SB 316 showed the maximum nodulations.

Yield - Soybean crop yield is considered by its fruit number, the number of seeds, and seeds weight. The result presented in Table 2 shows that the yield and yield attributes were significantly affected by the different Rhizobium inoculations. The highest number of fruits, number of seeds, and 100 seed weights were $216.8,420$, and $12 \mathrm{gm}$, respectively, which is obtained from SB 316 inoculation. Similarly, the maximum yield/plant and yield/ha were also found from the SB 316 inoculation. The highest yield/plant and yield/ha were $50.4 \mathrm{gm} /$ plant and $2.71 \mathrm{t} / \mathrm{ha}$, respectively, while the minimum was $19.6 \mathrm{gm} / \mathrm{plant}$ and $1.05 \mathrm{t} / \mathrm{ha}$, which are found from the control treatment.

Table 2:Yield attributes of soybean in different treatments

\begin{tabular}{|c|c|c|c|c|c|}
\hline Treatment & $\begin{array}{c}\text { Fruits } \\
\text { number/plant }\end{array}$ & Seeds/plant & $\begin{array}{c}\text { 100-Seed weight } \\
(\mathbf{g m})\end{array}$ & Yield (gm/plant) & Yield (t/ha) \\
\hline Control & $103.5 \mathrm{~d}$ & $194 \mathrm{~d}$ & $10.1 \mathrm{e}$ & $19.6 \mathrm{~d}$ & $1.05 \mathrm{~d}$ \\
\hline SB 66 & $108 \mathrm{~cd}$ & $202 \mathrm{~cd}$ & $10.8 \mathrm{bcd}$ & $21.8 \mathrm{~cd}$ & $1.17 \mathrm{~cd}$ \\
\hline SB 321 & $157 \mathrm{~b}$ & $301 \mathrm{~b}$ & $11 \mathrm{~b}$ & $33.2 \mathrm{~b}$ & $1.79 \mathrm{~b}$ \\
\hline SB 306 & $183.3 \mathrm{ab}$ & $350 \mathrm{ab}$ & $11.8 \mathrm{a}$ & $41.1 \mathrm{ab}$ & $2.21 \mathrm{ab}$ \\
\hline SB 316 & $216.8 \mathrm{a}$ & $420 \mathrm{a}$ & $12 \mathrm{a}$ & $50.4 \mathrm{a}$ & $2.71 \mathrm{a}$ \\
\hline SB 343 & $171.8 \mathrm{ab}$ & $330 \mathrm{ab}$ & $10.9 \mathrm{bc}$ & $36 \mathrm{~b}$ & $1.93 \mathrm{~b}$ \\
\hline SB 394 & $151.5 \mathrm{bc}$ & $288 \mathrm{bc}$ & $10.7 \mathrm{bcd}$ & $30.8 \mathrm{bc}$ & $1.65 \mathrm{bc}$ \\
\hline SB 433 & $107.8 \mathrm{~cd}$ & $203 \mathrm{~cd}$ & $10.5 \mathrm{cde}$ & $21.3 \mathrm{~cd}$ & $1.15 \mathrm{~cd}$ \\
\hline SB 212 & $104.5 \mathrm{~d}$ & $198 \mathrm{~cd}$ & $10.4 \mathrm{de}$ & $20.5 \mathrm{~cd}$ & $1.1 \mathrm{~cd}$ \\
\hline CV & 22.29 & 22.94 & 2.73 & 23.27 & 23.34 \\
\hline LSD & 46.85 & 91.94 & 0.43 & 10.29 & 0.55 \\
\hline
\end{tabular}

Rhizobium inoculations have a significant effect on soybean growth and yield. Rhizobium inoculation enhances the metabolism of the soybean plant, which promotes growth and nodulation. The resulting of better growth offers a healthy yield. In this study, SB 316 treatment was found to be the most significant inoculation for soybean production compared to other inoculations.

\section{CONCLUSION:}

The study was conducted to detect the effect of different biofertilizers on soybean growth and yield. Rhizobium inoculation enhances the metabolism of plants which increases the growth and yield of soybean. In this study, the effects of Rhizobium inoculation were found to be significantly higher than in control treatment. SB 316 was the most effective inoculation compared to other treatments used in the

UniversePG I $\underline{\text { www.universepg.com }}$ study that significantly increased plant growth, nodulation, and yield component.

\section{ACKNOWLEDGMENT:}

The authors would like to express their gratitude to College of Agricultural Sciences, International University of Business Agriculture and Technology (IUBAT), Dhaka, Bangladesh for theirconstructive cooperation throughout the research work.

\section{CONFLICTS OF INTEREST:}

The authors declared there are no conflicts of interest in publishing the research work.

\section{REFERENCES:}

1) Egamberdiyeva, D.,Qarshieva, D. and Davranov, K. (2004). The use of Bradyrhizobium to enhance growth and yield of soybean in calcareous soil in Uzbekistan. J. of plant growth regulation, 23(1), 54-57. https://doi.org/10.1007/s00344-004-0069-4 
2) Jaga, P.K. and Sharma, S.A.T.I.S.H. (2015). Effect of biofertilizer and fertilizers on productivity of soybean. Annals of Plant and Soil Research, 17(2), pp.171-174.

http://gkvsociety.com/control/uploads/Effect $\% 20$ of $\%$ 20bio-fertilizer $\% 20$ and $\% 20$ fertilizers $\% 20$ on $\% 20$ pro ductivity\%20of\%20soybean.pdf

3) Kazemi, S., Galeshi, S.A., Ghanbari, A. and KIANOUSH, G.A. (2005). Effects of sowing date and rhizobium inoculation on yield and its components in soybean.

https://www.sid.ir/en/Journal/ViewPaper.aspx? $\mathrm{ID}=4$ $\underline{4318}$

4) Langemeier, M. and Purdy, R. (2019). International Benchmarks for Soybean Production. Department of Agricultural and Consumer Economics, University of Illinois at Urbana-Champaign, farmdoc daily, 9: 94.

https://farmdocdaily.illinois.edu/2019/05/internationa 1-benchmarks-for-soybean-production-3.html

5) Rabiul I, Uddin ME, and Alam MF. (2020). "Isolation, identification and characterization of Rhizobium species from soil of Cicer arietinum field of Faridpur in Bangladesh,” Intern. J. of Curr. Res., 12(4), 10322-10325.

https://doi.org/10.24941/ijcr.38456.04.2020

6) Rahman MM, Hasna MK, Shumsun N, Hasan R. Islam MN, Kabir MH, and Delwar M Hossain. (2020). Evaluation of some fungicides against collar rot Disease of soybean. Am. J. Pure Appl. Sci., 2(5), 159-166. https://doi.org/10.34104/ajpab.020.01590166

7) Sultana, M.M., Haque, M.A., Reza, M.S.A. and Chowdhury, M.A.H. (2014). Performance of rhizobia and nitrogen on nodulation yield and $\mathrm{N}$ uptake by soybean in saline soil. Journal of Environmental Science and Natural Resources, 7(1), pp.215-226. https://doi.org/10.3329/jesnr.v7i1.22174

8) Yadav, K.K. and Sarkar, S. (2019). Biofertilizers, impact on soil fertility and crop productivity under sustainable agriculture. Environment and Ecology, 37(1), pp.89-93.

https://www.researchgate.net/publication/329238918 Biofertilizers Impact on Soil Fertility and Crop Productivity under Sustainable Agriculture

Citation: Islam MN, Sharmin S, and Rahman MA. (2021). Effects of different biofertilizer on soybean (Glycine max) production. Am. J. Pure Appl. Sci., 3(3), 55-59.

https://doi.org/10.34104/ajpab.021.055059 @) (9) 